\title{
PERSEPSI MASYARAKAT TERHADAP DESA WISATA TEGALWARU DI CIAMPEA BOGOR
}

\author{
Community Perception of Tegalwaru Tourism Village \\ in Ciampea Bogor
}

\author{
Muhtar Mochamad Solihin ${ }^{1 *}$, Atikah Rahmah Lubis ${ }^{2}$, Christian Pratama Putra ${ }^{3}$ \\ ${ }^{1}$ UIN Syarif Hidayatullah Jakarta \\ 2 Institut Pertanian Bogor \\ ${ }^{3}$ Sekolah Tinggi Pertanian Kutai Timur \\ *Email: muhtarsolihin@uinjkt.ac.id
}

\begin{abstract}
The existence of the Tegalwaru Business Tourism Area (KWBT) is a business innovation that has been the development of the community's Small and Medium Enterprises (SMEs) strategy that has existed for a long time. The existence of a business innovation that is a source of additional income for the community that should make the community support it by participating in advancing Tegalwaru Village as a village center for SMEs in Bogor. The aims of this study are 1) to describe the people of Tegalwaru Village, 2) to explain the community's perception of the Tegalwaru Tourism Village, 3) to analyze the factors related to the community's perception of the Tegalwaru Tourism Village. The research approach uses quantitative with the census method. Methods of data collection by distributing questionnaires, interviews and observations. Data analysis used descriptive and inferential analysis (Spearman rank correlation). The results of the study show that: 1) the majority of the people of Tegalwaru Village are in the adult category (40-60 years), the average education of the respondents is in the middle group, namely between SMA-S1, and the income of SME owners in collaboration with KWBT have an income of more than IDR 2,500,000 per month; 2) the result of calculating the average score of 27 means that the perception of SME owners is positive towards the existence of KWBT, 3) factors related to public perception of KWBT are the choice of information, sources of information, relative advantage and level of adjustment.
\end{abstract}

Keywords: access to information, tourist village areas, public perception

\begin{abstract}
ABSTRAK
Keberadaan Kawasan Wisata Bisnis Tegalwaru (KWBT) merupakan sebuah inovasi bisnis yang menjadi strategi pengembangan Usaha Kecil dan Menengah (UKM) masyarakat yang sudah ada sejak lama. Adanya sebuah inovasi bisnis yang menjadi sumber tambahan pendapatan lain bagi masyarakat seharusnya menjadikan masyarakat mendukung dengan berpartisipasi memajukan Desa Tegalwaru sebagai desa pusat wisata UKM yang ada di Bogor. Tujuan penelitian ini adalah 1) mendeskripsikan karakteristik masyarakat Desa Tegalwaru, 2) menjelaskan persepsi masyarakat tentang Desa Wisata Tegalwaru, 3) menganalisis faktor-faktor yang berhuungan dengan persepsi masyarakat tentang Desa Wisata Tegalwaru. Pendekatan penelitian mengunakan kuantitatif dengan metode sensus. Metode pengumpulan data dengan penyebaran kuesioner, wawancara dan observasi. Data dianalisis menggunakan analisis deskriptif dan inferensial (korelasi rank Spearman). Hasil penelitian menunjukkan bahwa: 1) mayoritas masyarakat Desa Tegalwaru masuk ke dalam kategori dewasa (40-60 tahun), pendidikan responden rata - rata masuk pada kelompok menengah yaitu antara SMA-S1, dan penghasilan pemilik UKM yang bekerjasama dengan KWBT pada kategori tinggi dengan penghasilan lebih besar Rp 2.500.000 per bulan; 2) hasil perhitungan rataan skor sebesar 27 memiliki arti bahwa persepsi pemilik UKM bersifat positif terhadap keberadaan KWBT, 3) faktor yang berhubungan dengan persepsi masyarakat tentang KWBT adalah kesesuaian informasi, kredibilitas sumber informasi, keunggulan relatif dan tingkat kesesuaian.
\end{abstract}

Kata Kunci: akses informasi, kawasan desa wisata, persepsi masyarakat 


\section{Pendahuluan}

Dewasa ini Indonesia masih menjadi negara berkembang dengan jumlah penduduk sebesar 260 juta jiwa. Jumlah tersebut menempatkan Indonesia pada urutan kelima terbanyak dunia. Sementara urutan pertama masih di duduki oleh negara China (CIA 2017). Berdasarakan penelitian yang dilakukan Arianto et al. (2015) menyebutkan bahwa tingginya jumlah penduduk tersebut sejalan dengan pertumbuhan ekonomi. Sementara Prok (2015) menjelaskan bahwa angkatan kerja menjadi faktor yang berpengaruh terhadap pertumbuhan ekonomi.

Pertumbuhan ekonomi merupakan sebuah tujuan yang harus terjadi pada pembangunan suatu negara atau wilayah. Pencapaian tujuan tersebut menjadikan pertumbuhan ekonomi sebagai salah satu indikator keberhasilan pembangunan ekonomi yang dijalankan. Dalam pembangunan ekonomi baik yang bersifat mikro maupun makro akan selalu dihadapkan pada persoalan lain seperti sosial, politik, budaya dan ekonomi itu sendiri. Berbagai persoalan tersebut bisa saja menjadi faktor pendukung atau bahkan menjadi penghambat dalam pembangunan ekonomi yang direncanakan dan dijalankan.

Salah satu upaya dalam mengatasai persoalan yang tidak diinginkan (baca: menjadi penghambat) tersebut dapat diantisipasi melalui proses sinergitas antar aspek yang ada secara seimbang. Proses saling bersinergi antar aspek tersebut sebagai jalan memudahkan dan mempercepat keberhasilan pembangunan ekonomi baik di tingkat pusat maupun daerah. Menurut Alam (2006) pembangunan ekonomi merupakan suatu proses yang bertujuan untuk menaikkan Produk Domestik Bruto (PDB) suatu negara atau daerah dalam jangka panjang. Secara sederharna pembangunan ekonomi tersebut sebagai sebuah proses yang memiliki tujuan untuk menaikan PDB negara atau daerah yang melebihi pertumbuhan penduduk. Frisdiantara \& Mukhklis (2016) menjelaskan bahwa pembangunan ekonomi merupakan proses yang berlangsung terus menerus dalam mengolah sumber daya ekonomi yang ada untuk mencapai tujuan kesejahteraan rakyat. Dalam hal ini peran sumber daya ekonomi dalam pembangunan sangat penting untuk mendorong pencapaian tujuan pembangunan ekonomi. Sementara Arsyad (1999) menjelaskan pembangunan ekonomi sebagai proses kerjasama antara pemerintah daerah dengan masyarakat dalam mengelola sumberdaya-sumberdaya ekonomi yang ada dengan tujuan menciptakan lapangan kerja baru dan merangsang perkembangan kegiatan ekonomi di daerah sehingga mendukung tercapainya tujuan pembangunan ekonomi nasional yaitu kesejahteraan masyarakat.

Terkait hal tersebut Desa Tegalwaru merupakan desa yang berupaya mengelola sumberdaya ekonomi yang ada untuk membantu dan mendukung pencapaian tujuan pembangunan ekonomi daerah dan nasional dalam jangka panjang. Proses pembangunan ekonomi yang dijalankan Desa Tegalwaru tersebut sebagai salah satu bentuk inovasi bisnis dalam pemanfaatan sumbedaya ekonomi yang tersedia. Inovasi menurut Levis (1996) adalah gagasan, tindakan atau teknologi termasuk barang yang dianggap baru oleh seseorang. Sejauh dihubungkan dengan perilaku manusia, inovasi tersebut tidak mesti harus baru dari yang semula tidak ada menjadi ada, tetapi diukur dari selang waktu penggunaan oleh orang yang menganggap hal tersebut baru baginya. Sumber pemahaman konsep yang dibangun adalah setiap ide pernah menjadi inovasi karena setiap inovasi merupakan ide. Inovasi yang ada dapat mempunyai komponen ide dan wujud fisik atau hanya berupa komponen ide. Inovasi yang memiliki komponen ide dan 
wujud fisik seperti traktor, pupuk, pestisida dan sebagainya dapat diadopsi dengan keputusan tindakan nyata. Sementara inovasi yang hanya memiliki komponen ide tidak dapat diadopsi secara fisik, tapi hanya dengan keputusan simbolis.

Konsep bisnis wisata yang dijalankan Desa Tegalwaru secara sederhana merupakan sebuah inovasi bisnis desa wisata. Inovasi bisnis tersebut dijalankan dengan memanfaatkan potensi wilayah yang sudah ada sejak puluhan tahun lalu sebagai sumber tambahan pendapatan ekonomi masyarakat. Potensi wilayah Desa Tegalwaru tersebut dapat dilihat dari keberadaan beragam UKM sebagai mata pencaharian masyarakat yang cukup strategis dalam mendukung pembangunan ekonomi daerah dan nasional. Sampai saat ini Desa Tegalwaru memiliki 39 buah UKM dan terdapat 20 UKM yang kemudian dijadikan sebagai objek wisata untuk desa wisata bisnis industri rumahan. UKM yang sudah ada di Desa Tegalwaru sejauh ini terdiri dari UKM tas, UKM brownis, UKM pandai besi, UKM ternak sapi, ternak kambing, UKM tanaman herbal, sampai UKM goes digital.

Selain itu kondisi geografis lingkungan Tegalwaru yang asri di dataran Gunung Salak Endah memberikan keuntungan tersendiri bagi masyarakat dalam menjadikan desanya sebagai objek wisata Kawasan Wisata Bisnis Tegawaru (KWBT). Kemenparekraf (2012) menjelaskan bahwa desa wisata merupakan sebuah kawasan perdesaan yang memiliki beberapa karakteristik khusus untuk menjadi daerah tujuan wisata. Karakteristik khusus tersebut yaitu penduduknya masih memiliki tradisi dan budaya, alam dan lingkungan yang relatif masih asli, serta memiliki faktor pendukung seperti makanan khas, sistem pertanian dan sistem sosial.

Meskipun sudah banyak masyarakat dari daerah lain yang berkunjung sebagai wisatawan karena tertarik dengan keberadaaan KWBT sebagai objek wisata bisnis, tetapi bisnis KWBT yang dikembangkan dengan tujuan menjadi pusat wisata bisnis UKM yang ada di Bogor tidak serta merta berjalan lancar. Hal tersebut dapat dilihat dari hasil observasi yang dilakukan peneliti menunjukkan terdapat beberapa masyarakat (pemilik UKM) yang kurang merespons dengan baik atas inovasi yang ditawarkan lbu Tatiek sebagai pencetus KWBT tersebut. Kondisi tersebut ditunjukkan dengan kurangnya sinergitas antar UKM yang ada dengan pengelola inovasi KWBT itu sendiri sehingga memunculkan beragam persepsi di masyarakat. Terlebih lagi komunikasi yang dibangun antar pemilik UKM dengan pengelola KWBT terlihat kurang intensif dan efektif.

Padahal keberadaan inovasi bisnis KWBT secara nyata dapat menjadi sumber tambahan pendapatan lain bagi masyarakat yang seharusnya menjadikan masyarakat mendukung keberadaan KWBT. Maka dari itu, menjadi penting dan menarik dilakukan penelitian tentang persepsi masyarakat terhadap keberadaan Desa Wisata KWBT. Persepsi sendiri merupakan pandangan seseorang terhadap suatu objek yang ditangkap melalui panca indera (Rakhmat 2012). Menurut Widi (2006) persepsi masyarakat dapat bersifat positif maupun negatif yang diasumsikan sebagai sebuah file yang sudah tersimpan rapih di dalam alam pikiran bawah sadar kita. File tersebut akan segera muncul terbuka ketika adanya stimulus yang memicunya. Persepsi tersebut merupakan hasil kerja otak dalam memahami atau menilai suatu hal yang terjadi di sekitarnya.

Berdasarkan latar belakang permasalahan tersebut, maka rumusan masalah penelitian ini, yaitu: 1) bagaimana karakteristik masyarakat Desa Wisata Tegalwaru?, 2) bagaimana persepsi masyarakat tentang Desa Wisata Tegalwaru, dan 3) apa saja faktor-faktor yang berhubungan dengan 
persepsi masyarakat tentang Desa Wisata Tegalwaru?

Metode
Penelitian ini dirancang
menggunakan pendekatan kuantitatif
dengan metode sensus. Lokasi
penelitian dilakukan di Kawasan Wisata
Bisnis Tegalwaru (KWBT) Kecamatan
Ciampea Kabupaten Bogor. Desa
Tegalwaru dipilih dengan pertimbangan bahwa desa tersebut sebagai desa wisata yang sudah di kenal masyarakat sekitar dan luar Bogor. Adapun waktu penelitian lapangan dilaksanakan pada tanggal 5 Maret sampai 5 Mei 2017. Populasi dan sampel penelitian adalah seluruh pemilik UKM di Kawasan Wisata Bisnis Tegalwaru (KWBT) yang bekerjasama dengan KWBT sebanyak 20 orang. Oleh karena itu metode penelitian ini menggunakan sensus sehingga responden penelitian ini adalah seluruh anggota populasi berjumlah 20 orang.

Variabel penelitian yang diamati meliputi tiga variabel bebas (independent variabele) dan satu variabel terikat (dependent variable). Ketiga variabel bebas dalam penelitian ini yaitu, karakteristik responden $\left(\mathrm{X}_{1}\right)$ yang terdiri dari Usia, pendidikan dan pendapatan, akses informasi $\left(X_{2}\right)$ yang terdiri dari sumber informasi, kesesuaian informasi dan kredibilitas sumber informasi, dan karakteristik desa wisata $\left(X_{3}\right)$ yang terdiri dari tingkat kesesuaian, kerumitan, dapat dicoba, dan dapat diamati. Adapun variabel terikat disini adalah persepsi masyarakat terhadap desa wisata $\left(\mathrm{Y}_{1}\right)$ yang terdiri dari pengembangan desa wisata, pelatihan, dan partisipasi.

Metode pengumpulan data dengan observasi, wawancara dan penyebaran kuesioner. Kuesioner yang digunakan sudah dilakukan uji coba terlebih dahulu kepada mahasiswa pascasarjana penyuluhan pembangunan yang dianggap memahami objek penelitian. Hasil analisis uji kuesioner disimpulkan bahwa jumlah pernyataan yang valid sebanyak 21 dari 28 pernyataan yang ada. Dari 7 pernyataan yang tidak valid tersebut dilakukan perbaikan kalimat (tata bahasa) agar menjadi lebih jelas dan mudah dipahami responden. Adapun hasil uji reliabilitas kuesioner penelitian menunjukkan hasil bahwa kuesioner penelitian reliabel dengan nilai koefisien Cronbach Alpha sebesar 0,732 .

Data inti penelitian dianalisis menggunakan statistik deskriptif untuk mendeskripsikan karakteristik dan persepsi masyarakat Desa Tegalwaru, dan statistik inferensial (korelasi rank Spearman) untuk menganalisis faktorfaktor yang berhubungan dengan persepsi masyarakat tentang Desa Wisata Tegalwaru.

\section{Hasil dan Pembahasan Karakteristik Responden}

Karakteristik responden dalam penelitian ini adalah ciri-ciri yang melekat pada individu responden yang diamati meliputi Usia, pendidikan dan pendapatan.

\section{Usia}

Usia merupakan salah satu karakteristik yang penting untuk mengetahui persepsi pemilik UKM terhadap inovasi KWBT. Usia disini adalah lamanya hidup pemiliki UKM dari lahir sampai dilakukannya pencarian data penelitian melalui kuesioner. Berdasarkan hasil analisis deskriptif mengenai karaktersitik Usia responden dapat dilihat pada Tabel 1. 
Tabel 1 Gambaran umum Usia individu pemilik UKM dalam aktifitasnya bersama KWBT Desa Tegalwaru

\begin{tabular}{lccc}
\hline $\begin{array}{l}\text { Kategori } \\
\text { Usia (tahun) }\end{array}$ & $\begin{array}{c}\text { Jumlah } \\
\text { Responden (Org) }\end{array}$ & Rataan (tahun) & Responden (\%) \\
\hline Muda (20-39) & 8 & 33,88 & 40 \\
Dewasa (40-60) & 9 & 47,55 & 45 \\
Tua (>60) & 3 & 68,40 & 15 \\
Total & 20 & 49,92 & 100 \\
\hline
\end{tabular}

Berdasarkan Tabel 1 menunjukkan bahwa rata-rata Usia pemilik UKM yang bekerjasama dengan KWBT adalah 50 tahun dengan variasi mulai dari 25 tahun sampai dengan 75 tahun. Presentase kelompok Usia terbesar masuk ke dalam kategori dewasa (40-60 tahun) sebesar 45 persen dengan rata-rata Usia sekitar 47 tahun. Menurut Van den Ban dan Hawkins (1999) serta Rakhmat (2012) pengalaman masa lalu dapat mempengaruhi persepsi seseorang terhadap suatu hal. Artinya semakin banyak pengalaman kerja seseorang maka ia akan mudah menerima suatu inovasi. Akan tetapi jika Usia sudah tua maka akan mempengaruhi penurunan dalam menerima inovasi. Hal ini sesuai dengan pendapat Silien (1998) yang menyatakan bahwa semakin tua Usia seseorang maka penerimaan terhadap hal-hal baru semakin rendah. Hal tersebut akibat adanya kecenderungan golongan tua untuk selalu bertahan dengan nilai-nilai lama (turun temurun) sehingga diperkirakan sulit menerima inovasi.

\section{Pendidikan Responden}

Pendidikan menjadi salah satu karakteristik responden yang diamati karena menjadi hal yang penting dianalisis untuk melihat persepsi pemilik UKM terhadap inovasi KWBT. Pendidikan disini adalah jenjang pendidikan formal terakhir yang telah diselesaikan pemilik UKM sampai penelitian dilakukan. Berdasarkan hasil analisis data mengguanakan statistik deskriptif diperoleh informasi bahwa pendidikan responden rata - rata masuk pada kelompok menengah yaitu antara SMA-S1. Secara lebih jelas informasi tersebut dapat dilihat pada Tabel 2 .

Tabel 2 Gambaran umum tingkat pendidikan individu pemilik UKM dalam aktifitasnya bersama KWBT Desa Tegalwaru

\begin{tabular}{lcc}
\hline Kategori & $\begin{array}{c}\text { Jumlah Responden } \\
\text { Tingkat Pendidikan }\end{array}$ & Responden (\%) \\
\hline Rendah (SSMP) & 8 & 40 \\
Sedang (SMA-S1) & 12 & 60 \\
Tinggi ( $\geq$ S2) & 0 & 0 \\
Total & 20 & 100 \\
\hline
\end{tabular}

\begin{abstract}
Pemilik UKM yang bekerjasama dengan KWBT lebih banyak berpendidikan SMA hingga S1 yaitu sebanyak 12 orang. Hal ini dikarenakan perbedaan kognitif menyebabkan persepsi seseorang berbeda satu sama lain (Van den Ban dan Hawkins, 1999).
\end{abstract}

Artinya bahwa semakin tinggi pendidikan seseorang maka ia akan lebih mudah menerima suatu inovasi.

\section{Pendapatan Responden}

Pendapatan sebagai salah satu karakteristik responden yang dinilai 
penting untuk menganalisis persepsi pemilik UKM terhadap inovasi KWBT. Pendapatan disini adalah jumlah ratarata penghasilan yang diperoleh pemilik UKM per bulan yang diukur dalam satuan rupiah. Hasil analisis deskriptif diperoleh informasi bahwa tingkat pendapatan pemilik UKM berada pada kategori tinggi seperti yang terlihat pada Tabel 3.

Tabel 3 Gambaran umum pendapatan individu pemilik UKM dalam aktifitasnya bersama KWBT Desa Tegalwaru

\begin{tabular}{lcc}
\hline Kategori & $\begin{array}{c}\text { Jumlah Responden } \\
\text { Pendapatan }\end{array}$ & Responden (\%) \\
\hline Rendah & 0 & 0 \\
Sedang & 7 & 35 \\
Tinggi & 13 & 65 \\
Total & 20 & 100 \\
\hline
\end{tabular}

\footnotetext{
Berdasarkan Tabel 3 menunjukkan bahwa rata-rata penghasilan pemilik UKM perbulan yang bekerjasama dengan KWBT masuk pada kelompok berpendapatan tinggi sebesar 65 persen dengan penghasilan lebih dari $\mathrm{Rp}$ 2.500.000. Sementara sisanya masuk pada kategori sedang dengan jumlah rata-rata penghasilan perbulan antara $\mathrm{Rp} 1.500 .000$ sampai dengan Rp 2.500.000. Pengelompokan pendapatan pada kategori rendah, sedang, tinggi berdasarkan penggolongan Badan Pusat Statistik (BPS) pada tahun 2008.
}

\begin{abstract}
Persepsi Masyarakat tentang Desa Wisata Tegalwaru

Keseluruhan unsur persepsi pemilik UKM diidentifikasikan ke dalam kuesioner dengan 8 buah pernyataan yang diukur menggunakan skala ordinal dengan empat kategori jawaban yaitu (4) sangat setuju, (3) setuju, (2) tidak setuju dan (1) sangat tidak setuju. Hasil analisis deskriptif dengan skoring, masing-masing digolongkan menjadi tiga kategori, yaitu negatif, netral dan positif dengan hasil perhitungan dapat dilihat pada Tabel 4.
\end{abstract}

Tabel 4 Persepsi masyarakat tentang desa wisata Tegalwaru

\begin{tabular}{|c|c|c|c|}
\hline Item & Skoring & Jumlah (Org) & Responden (\%) \\
\hline Negatif (-) & $8-16$ & - & - \\
\hline Netral & $>16-24$ & 3 & 15 \\
\hline Positif $(+)$ & $>24-32$ & $\begin{array}{l}17 \\
20\end{array}$ & $\begin{array}{c}85 \\
100\end{array}$ \\
\hline
\end{tabular}

Keterangan: Skor rendah $\mathrm{x}$ jumlah pernyataan (1x8); skor tertinggi $\mathrm{x}$ jumlah pernyataan (4x8); interval (32-8); lebar kelas (24/3)

Hasil analisis rataan pada variabel persepsi (Y) seperti yang terlihat pada Tabel 4 diperoleh nilai rataan sebesar 27. Berdasarkan Tabel 4 dapat dilihat bahwa sebagian besar dari responden memiliki persepsi positif terhadap keberadaan kawasan wisata bisnis Desa Tegalwaru. Persepsi postif yang terbentuk ini antara lain disebabkan karena sebagian besar responden memahami dan merasakan dampak yang baik secara ekonomi dan 
sosial. Dampak ini berupa meningkatnya lapangan perkerjaan bagi masyarakat sekitar, semakin terkenalnya desa tegalwaru sehingga memudahkan dalam menarik pembeli. Hasil penelitian ini sejalan dengan penelitian Nisa et al (2011) bahwa masyarakat akan memiliki persepsi positif dengan menunjukkan sikap setuju daerah Hutan Pendidikan Mandiangin dikembangkan sebagai daerah tujuan wisata karena mereka telah mendapatkan penghasilan dari kegiatan wisata di Hutan Pendidikan Mandiangin.

\section{Faktor-Faktor yang Berhubungan dengan Persepsi Masyarakat tentang Desa Wisata Tegalwaru}

Analisis data untuk menganalisis hubungan antara karakteristik responden, akses informasi dan karakteristik desa wisata dengan persepsi masyarakat menggunakan bantuan perangkat lunak (software) Statistical Package for the Social Sciences (SPSS) 26. Hasil analisis korelasi rank Spearman diperoleh data bahwa terdapat hubungan positif dan signifikan (nyata) antara akses informasi dengan persepsi masyarakat tentang desa wisata. Adapun variabel lainnya seperti karakteristik responden, dan karakteristik desa wisata tidak menunjukkan hubungan yang berarti atau signifikan (nyata) dengan persepsi masyarakat tentang desa wisata. Meskipun demikian, apabila dilihat pada sub variabel ciri desa wisata menunjukkan bahwa variabel keunggulan relatif dan tingkat kesesuaian desa wisata memiliki hubungan yang positif dan signifikan (nyata) juga dengan persepsi masyarakat tentang desa wisata.

Hasil analisis tersebut memberikan makna bahwa persepsi masyarakat Desa Tegalwaru tentang KWBT ditentukan oleh kesesuaian informasi, kredibilitas sumber informasi, keunggulan relatif dan tingkat kesesuaian. Tabel 5 menunjukkan hasil keluaran analisis korelasi rank Spearman.

Tabel 5 Nilai Koefisien Korelasi Rank Spearman

\begin{tabular}{lcc}
\hline \multirow{2}{*}{ Variabel $(X 1$, X2, X3) } & \multicolumn{2}{c}{ Persepsi Masyarakat tentang Desa Wisata } \\
\cline { 2 - 3 } Usia & 0.041 & 0.864 \\
Pendidikan & 0.281 & 0.230 \\
Pendapatan & 0.020 & 0.934 \\
Karakteristik Responden (X1) & $\mathbf{0 . 0 6 3}$ & $\mathbf{0 . 7 9 0}$ \\
Ketersediaan Informasi & 0.392 & 0.088 \\
Kesesuaian Informasi & $0.558^{*}$ & 0.011 \\
Kredibilitas Sumber & $0.525^{*}$ & 0.018 \\
Akses Informasi (X2) & $\mathbf{0 . 4 9 6 ^ { * }}$ & $\mathbf{0 . 0 2 6}$ \\
Keunggulan Relatif & $0.708^{*}$ & 0.000 \\
Tingkat Kesesuaian & $0.464^{*}$ & 0.039 \\
Kerumitan & 0.211 & 0.373 \\
Dapat Dicoba & 0.067 & 0.780 \\
Dapa Diamati & 0.294 & 0.209 \\
Ciri Desa Wisata (X3) & $\mathbf{0 . 3 8 2}$ & $\mathbf{0 . 0 9 6}$ \\
\hline Ket. Hasil & &
\end{tabular}

Ket. Hasil olah data rank Spearman

Berdasarkan Tabel 5 menunjukkan bahwa faktor-faktor yang berhubungan secara nyata dengan persepsi masyarakat tentang desa wisata KWBT antara lain kesesuaian informasi, 
kredibilitas sumber, keunggulan relatif dan tingkat keseusuaian karena memiliki nilai signifikansi yang kurang dari $(<) \quad 0,05$. Apabila dilihat dari nilai koefisien korelasi $\left(r_{s}\right)$ rank Spearman diperoleh informasi bahwa kekuatan hubungan keempat faktor tersebut benilai antara sedang hingga kuat.

Faktor kesesuaian informasi berhubungan positif dan signifikan dengan persepsi masyarakat tentang desa wisata memiliki arti bahwa persepsi masyarakat tentang desa wisata ditentukan oleh kesesuaian informasi yang dilihat, dibaca dan didengar oleh masyarakat. Arah hubungannya yang positif memiliki makna bahwa semakin tinggi kesesuaian informasi yang diperoleh masyarakt maka semakin positif atau baik persepsi masyarakat tentang kegiatan desa wisata di KWBT. Sebaliknya, semakin rendah kesesuaian informasi yang diperoleh masyarakat, maka persepsi mereka semakin negatif tentang kegiatan desa wisata KWBT. Tinggi rendah dari kesesuaian informasi ini dapat dilihat dari siapa yang berbicara dan siapa yang mendengarkan. Artinya sumber informasi dan penerima informasi tentang desa wisata menjadi aktor penting yang dapat meningkatkan atau menurunkan kesesuaian informasi sehing berdampak pada keberlangsungan kegiatan desa wisata KWBT.

Berdasarkan hasil observasi di lapangan terkait kesesuaian informasi ditemukan bahwa informasi perencanaan yang disebarkan oleh pengelola KWBT cukup sesuai dengan pelaksanaan yang dilakukan di lapangan. Dengan demikian, cukup mudah bagi para pemilik UKM untuk bergabung menjadi bagian dari keigatan KWBT sebagai desa wisata.

Hasil analisis faktor lain menunjukkan bahwa terdapat hubungan positif dan signifikan antara kredibilitas sumber informasi dengan persepsi masyarakat tentang desa wisata KWBT. Artinya bahwa semakin tinggi kredibilitas sumber informasi di mata masyarakat, maka semakin baik pula persepsi yang ditimbulkan di kalangan masyakat. Begitupun sebaliknya bahwa semakin rendah kredibilitas sumber informasi, maka semakin rendah atau negatif persepsi masyarakat tentang desa wisata KWBT .

Berdasarkan hasil observasi di lapagan ditemukan bahwa sumber informasi dalam hal ini adalah pengelola KWBT berjumlah terlalu sedikit, yaitu hanya 3 orang. Maka dari itu, masih ada masyarakat pemilik UKM yang belum dapat dijangkau secara menyuluruh untuk diberikan informasi mengenai berbagai macam kegiatan yang dilakukan KWBT. Keterbatasan akan ketersediaan sumber tersebut dapat berdampak pada penilaian masyarakat terhadap kredibilitas sumber informasi. . Maka dari itu, tingkat kepercayaan atau kredibilitas pengelola KWBT dalam memberikan informasi terkait kegiatan KWBT dapat ditingkatkan dengan terus memberikan informasi yang sesuai kepada masyarakat Desa Tegalwaru khususnya pemilik UKM yang terlibat secara langsung dengan kegiatan KWBT.

Faktor keunggulan relatif dari ciri desa wisata memiliki hubungan positif dan signifikan dengan persepsi masyarakat tentang desa wisata. Arah hubungan yang positif tersebut memiliki arti bahwa semakin unggul desa wisata maka persepsi masyarakat tentang desa wisata akan semakin baik atau positif. Begitupun sebaliknya, semakin tidak unggul desa wisata yang sedang dijalankan maka persepsi masyarakat tentang desa wisata semakin buruh atau negatif. Faktor keunggulan relatif ini dapat dilihat dari ada tidaknya keuntungan ekonomi atau pendapatan tambahan yang diperoleh pemilik UKM sebagai hasil dari kerjasama dengan pengelola KWBT. Penilaian keunggulan relatif ini berdasarkan kepada manfaat, kenyamanan dan kepuasan yang dirasakan masyarakat pemilik UKM setelah terlibat dalam kegiatan KWBT. 
Kemudian faktor lain yang berhubungan positif dan signifikan dengan persepsi masyarakat tentang desa wisata adalah tingkat kesesuaian. Arah hubungan yang positif antara tingkat keseuaian dengan persepsi masyarakat tersebut memiliki arti bahwa semakin tinggi tingkat kesesuaian maka semakin baik persepsi masyarakat tentang desa wisata. Sebaliknya, semakin rendah tingkat kesesuaian maka akan semakin buruk persepsi masyarakat tentang desa wisata yang sedang dijalankan. Tingkat kesesuaian ini terkait cocok tidaknya keberadakan kegiatan KWBT dengan kebutuhan masyarakat selaku pemiliki UKM yang dijadikan sebagai subjek utama desa wisata KWBT. Penilaian faktor tingkat kesesuaian tersebut dilihat dari kegiatan yang dijalankan, ketersediaan sarana prasarana dan rutinitas kunjungan wisatawan yang bersamaan dengan proses produksi UKM.

Berdasakan hasil observasi di lapangan ditemukan fakta bahwa kegiatan desa wisata KWBT ini muncul belakangan daripada kegiatan UKM yang dijadikan sebagai subjek utama wisatawan. Kegiatan KWBT ini sebagai sebuah kegiatan bisnis desa wisata dengan mengajak para pemilik UKM yang ada untuk menjadi bagian dari kegiatan utama KWBT. Maka dari itu, kegiatan KWBT lahir atas keberadaan mayoritas masyarakat yang memiliki UKM dengan beragam jenis. Dengan demikian, tidak semua pemilik UKM Desa Tegalwaru sudah terlibat menjadi bagian dari KWBT.

\section{Simpulan}

\section{Simpulan dan Saran}

Hasil analisis yang dilakukan menyimpulkan bahwa karakteristik usia masyarakat Desa Tegalwaru mayoritas (95 persen) pada kategori usia muda dan dewasa. Adapun pendapatan masyarakat termasuk ke dalam kategori berpendapatan sedang dan tinggi. Adapun persepsi masyarakat tentang keberadaan Kawasan Wisata Tegalwaru sebagai suatu inovasi tergolong positif karena masyarakat merasakan manfaat nyata dari kegiatan desa wisata Tegalwaru. Faktor-faktor yang berhubungan dengan persepsi masyarakat tentang desa wisata KWBT terdiri dari kesesuaian informasi, kredibilitas sumber informasi, keunggulan relatif dan tingkat kesesuaian.

\section{Saran}

Pengelola KWBT dapat meningkatkan sistem pengelolaannya terutama dalam hal penjadwalan dan pemberitahuan informasi kunjungan wisatawan kepada para pemilik UKM. Dalam proses pengembangan KWBT oleh pengelola sebaiknya mempertimbangkan saran dan pendapat dari para pemilik UKM atau masyarakat di sekitar KWBT. Kegiatan KWBT ini dapat menjadi model bagi para pemilik UKM di wilayah lain dalam suatu wilayah untuk menjadi suatu komunitas desa wisata yang tentu perlu mendapat perhatian dari pemangku kebijakan (pemerintah).

\section{Daftar Pustaka}

Alam, S. (2006). Ekonomi untuk SMA dan MA kelas XI KTSP Standar Isi 2006. Jakarta: Erlangga

Arianto, CE., Sumarsono, S., \& Adenan, M. (2015). Pengaruh Jumlah Penduduk dan Angka Pengangguran terhadap Pertumbuhan Ekonomi Kabupaten Jember. Jurnal IImu Ekonomi Unej.

Arsyad, L. (1999). Ekonomi Pembangunan. Yogyakarta (ID): STIE YKPN

Faturochman. (2006). Pengantar Psikologi Sosial. Yogyakarta (ID): Pustaka Pelajar

Frisdiantara, C \& Mukhklis, I. (2016). Ekonomi Pembangunan Sebauah Kajian Teoritis dan Empiris. Malang: Lembaga 
Penerbitan

Universitas

Kanjuruhan Malang

Kemenparekraf. (2012). Rencana

Strategis Kepariwisataan dan

Ekonomi Kreatif Periode 2012-

2014. Jakarta: Kemenparekraf

Levis, LR. (1996). Komunikasi Penyuluhan Pedesaan.

Bandung: Citra Aditya Bakti

Manalu, BE., Latifah, S \& Patana, P. (2012). Persepsi Masyarakat Terhadap Pengembangan Ekowisata di Desa Huta Ginjang, Kecamatan Sianjur Mula-mula, Kabupaten Samosir, Provinsi Sumatera Utara.

Mardikanto, T. (2009). Sistem Penyuluhan Pertanian. Surakarta (ID): UNS Press

Miftah, T. (2003). Perilaku Organisasi Konsep Dasar dan Aplikasinya. Jakarta: PT Raja Grafindo Persada

Murianto. (2014). Potensi dan Persepsi Masyarakat serta Wisatawan terhadap Pengembangan Ekowisata di Desa Aik Berik Lombok Tengah. 1(1): Jumpa

Nisa, K., Fauzi, H \& Abrani. (2011). Persepsi Wisatawan dan Masyarakat Terhadap Wisata Alam di Areal Hutan Pendidikan Unlam Mandiangin, Kalimantan Selatan. 2(2). Jurnal Hutan Tropis: 119-126. Publisher: Kerjasama Fakultas Kehutanan Universitas Lambung Mangkurat dan PERSAKI Pusat.

Prok, K. (2015). Faktor-Faktor Yang Mempengaruhi Pertumbuhan Ekonomi Sulawesi Utara Selama Periode Otonomi Daerah 2001-2013. 15(3). Jurnal Berkala IImiah Efisiensi

Rakhmat, J. (2012). Psikologi Komunikasi. Bandung: PT Remaja Rosdakarya

Sarwono, SW. (1996). Pengantar Umum Psikologi. Jakarta: Bulan Bintang
Silien, SBJ. (1998). "Partisipasi Anggota Pokmas Desa Tertinggal Pada Kegiatan Proyek Inpres Desa Tertinggal (IDT)." Departemen IImu-IImu Sosial Pertanian. Fakultas Pertanian. IPB. Bogor. Slameto., Haryadi, FT \& Subejo. (2014). Faktor-Faktor yang Mempengaruhi Persepsi Beberapa Etnis Petani Terhadap Karakteristik Inovasi Pengelolaan Tanaman Terpadu Padi Sawah Di Lampung. Jurnal Pengkajian dan Pengembangan Teknologi Pertanian

Sukmana, O. (2003). Dasar-dasar Psikologi Lingkungan. Jakarta: Bayu Media

Van Den Ban AW \& Hawkins HS. (1999). Penyuluhan Pertanian. Yogyakarta: Kanisius

Widi. (2006). The Art of Re engineering Your Mind of Success. Jakarta: Gramedia 